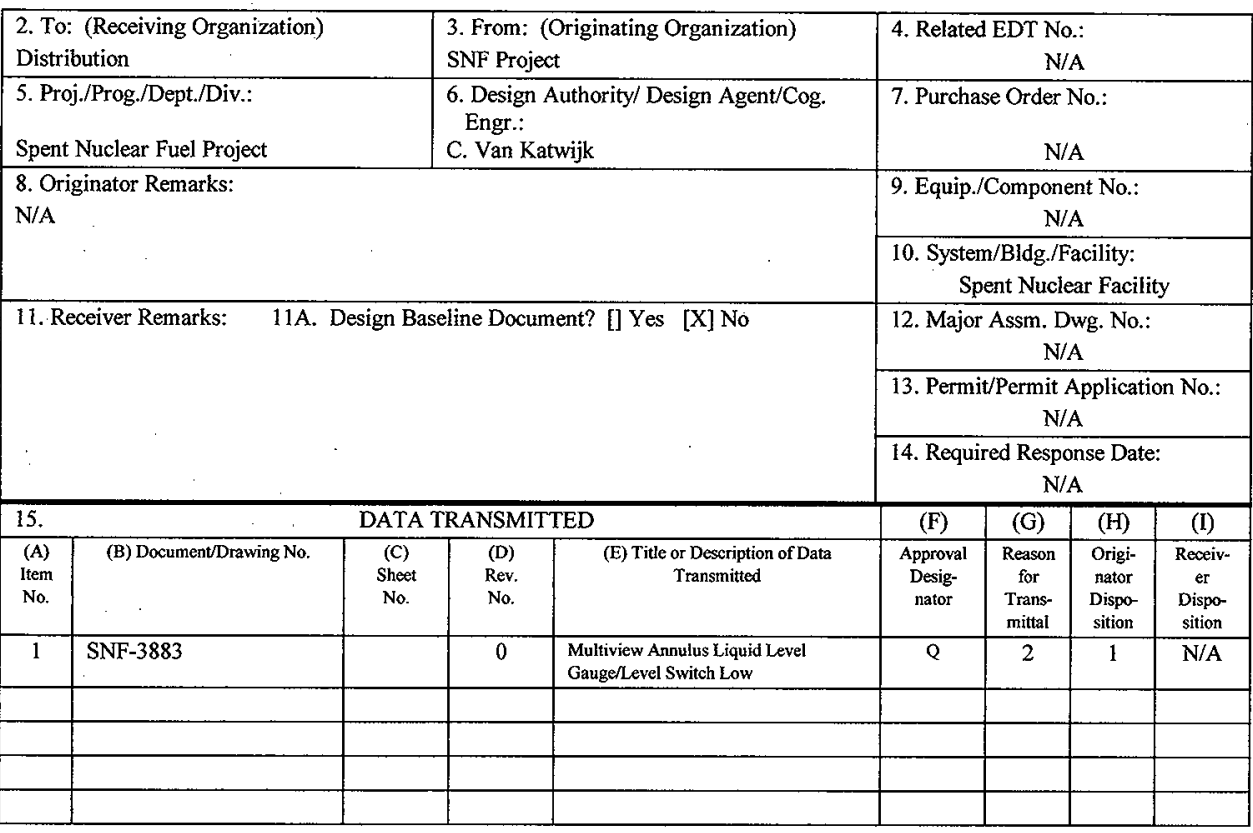

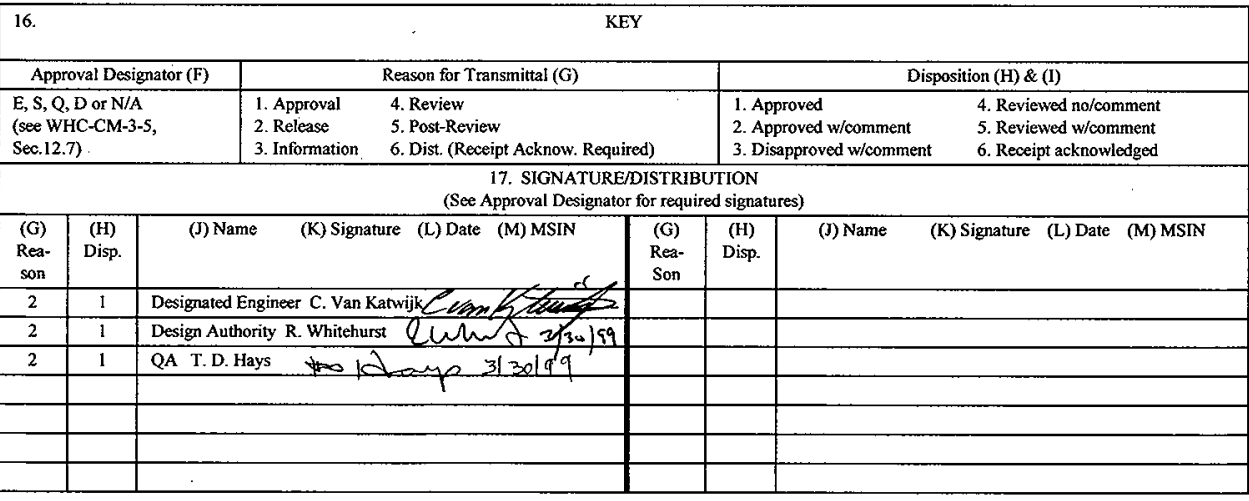
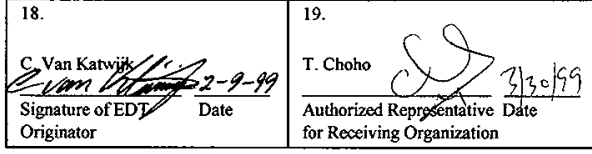

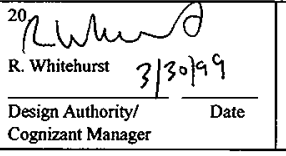

21. DOE APPROVAL (if required)

Ctrl, No.

1] Approved

[] Approved w/comments

D Disapproved w/comments 


\section{Reotemp Pressure Indicator, Local Indication of MCO Pressure}

Carl Van Katwijk

Numatec Hanford Co, Richland, WA 99352

U.S. Department of Energy Contract DE-AC06-96RL13200

EDT/ECN: 626257

UC: 620

Org Code: $2 \mathrm{G} 300$

Charge Code: $105559 / \mathrm{A} 000$

B\&R Code: $39 \mathrm{EW} 40400$

Total Pages: 13

Key Words: Pressure Indicator, MCO

Abstract: Reotemp Pressure Indicator, Local Indication of MCO Pressure CGI-SNF-D-07-P4-008

TRADEMARK DISCLAIMER. Reference herein to any specific commercial product, process, or service by trade name, trademark, manufacturer, or otherwise, does not necessarily constitute or imply its endorsement, recommendation, or favoring by the United States Government or any agency thereof or its contractors or subcontractors.

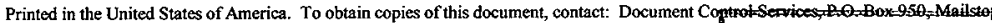
H6-08, Richland WA 99352, Phone (509) 372-2420; Fax (509) 376-4989.

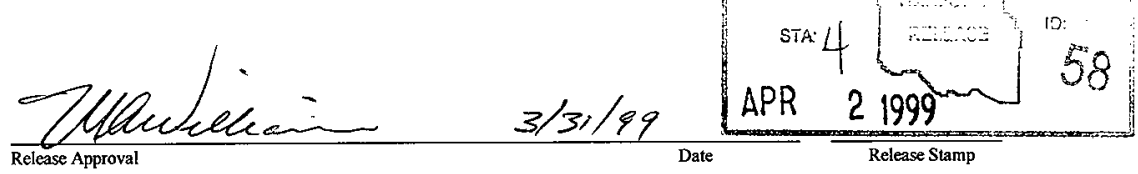


Title: REOTEMP PRESSURE INDICATOR, LOCAL INDICATION OF MCO PRESSURE

\begin{tabular}{|c|c|c|c|}
\hline Item No: NA & \multicolumn{2}{|l|}{ Manufacturer: } & Supplier: \\
\hline \multicolumn{2}{|l|}{ Mfg. Part/Model No.: } & \multicolumn{2}{|l|}{ Supplier's P/N: } \\
\hline \multicolumn{4}{|l|}{ Part Description: } \\
\hline \multicolumn{4}{|l|}{ End Use Description: } \\
\hline \multicolumn{4}{|c|}{ 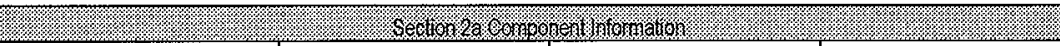 } \\
\hline $\begin{array}{l}\text { Equipment No:: VPS-PI- } \\
1 * 40, \mathrm{PI}-1 * \mathbf{4 1}\end{array}$ & $\begin{array}{l}\text { Specification No.: W-441- } \\
\text { P4, Rev. } 2\end{array}$ & Manufacturer: Reotemp & Past P.O. No.: NA \\
\hline $\begin{array}{l}\text { Manufacturer's Part Model } \\
\text { No.: PR-25-S-1-A-4- } \\
\text { P15-D }\end{array}$ & Equipment Supplier (if differer & from manufacturer): TBD & $\begin{array}{l}\text { Equip. Supplier's Part No.: } \\
\text { NA }\end{array}$ \\
\hline \multicolumn{4}{|c|}{$\begin{array}{l}\text { Component Description: Pressure indicator, } 0-15 \text { psig, } 2.5^{\prime \prime} \text { diameter; provide local indication of MCO } \\
\text { pressure. }\end{array}$} \\
\hline \multicolumn{4}{|c|}{ I. } \\
\hline \multicolumn{4}{|c|}{ 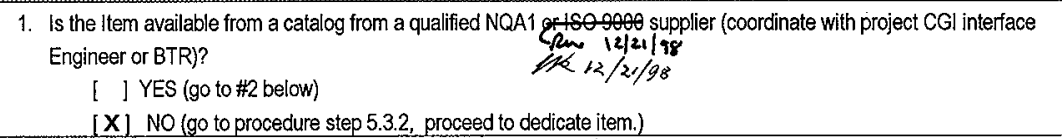 } \\
\hline \multicolumn{4}{|c|}{ 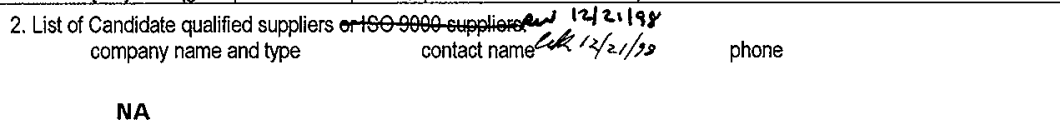 } \\
\hline \multicolumn{4}{|c|}{$\begin{array}{l}\text { 3. Recommended Procurement Strategy (coordinate with project CGI interface Engineer or BTR): } \\
\text { NA }\end{array}$} \\
\hline \multicolumn{4}{|c|}{ l. } \\
\hline \multicolumn{4}{|c|}{$\begin{array}{l}\text { 1. Question \#1: Is the ltem subject to design or specification requirements that are unique to nuclear facilities or activities? } \\
\begin{array}{l}\text { [ I YES (the ltem is not commercial grade) } \\
{[\mathrm{X}] \text { NO (continue) }}\end{array}\end{array}$} \\
\hline $\begin{array}{l}\text { 2. Question \#2: Is the Ite } \\
\text { l ] NO (the item i } \\
{[X] \text { YES (continue) }}\end{array}$ & $\begin{array}{l}\text { sed in applications other than } n \\
\text { commercial grade) }\end{array}$ & clear facilities or activities? & \\
\hline
\end{tabular}




\section{ECN No. NA CGI No.CGI-SNF-D-07-P4-008 \\ Title: REOTEMP PRESSURE INDICATOR, LOCAL INDICATION OF MCO PRESSURE}

3. Question \#3: Is the Item ordered from manufacturer/supplier on the basis or specifications set forth in the manufacturers catalog?

[ ] NO (the ltem is not commercial grade)

[X] YES (continue)

[X] All three criteria have been satisfied. The Item meets the definition of commercial grade.

\begin{tabular}{|c|c|}
\hline$[\mathbf{X}]$ & $\begin{array}{l}\text { Item is being purchased from a non ESL manufacturer supplier as commercial grade to be used in a Safety Class } \\
\text { application. }\end{array}$ \\
\hline [ ] & $\begin{array}{l}\text { Item is being purchased from a non ESL manufacturer supplier as commercial grade to be used in a Safety Significa } \\
\text { application. }\end{array}$ \\
\hline$[$ ] & $\begin{array}{l}\text { Item was purchased from a non ESL manufacturer supplier as commercial grade to be used in a Safely Class } \\
\text { application. }\end{array}$ \\
\hline [ ] & $\begin{array}{l}\text { Item was purchased from a non ESL manufacturer supplier as commercial grade to be used in a Safety Significant } \\
\text { application. }\end{array}$ \\
\hline [ ] & Other ('like-for-like', similar, su'bstitution, replacement evaluation) \\
\hline
\end{tabular}

A. Part/Component Safety Function:

1. Pressure Boundary Integrity

2. Non-powered local indication monitoring of $\mathrm{MCO}$ pressure for $\mathrm{H} 2$ explosion.

3. Maintain critical function after seismic event.

B. Part/Component Functional Mode:

Safety Function \#1:

[ ] Active - Mechanical or Electrical change of state is required to occur for the component to perform its safety function

[X] Passive - Change of state is not required for the component to perform its safety function Safety Function \#2:

[X] Active - Mechanical or Electrical change of state is required to occur for the component to perform its safety function.

[ ] Passive - Change of state is not required for the component to perform its safety function Safety Function \#3:

[ ] Active - Mechanical or Electrical change of state is required to occur for the component to perform its safety function.

[X] Passive - Change of state is not required for the component to perform its safety function

C. Host Component Safety Function (if applicable):

1. NA

2.

3. 
D. Failure Mechanisms(s) and the effects on component or system safety function (see worksheet 1):

1. PI process connection break/PI body break - inleakage of air/release of MCO contents through the pressure boundary.

2. Failure in gage movement mechanism resulting in inaccurate or loss of MCO pressure indication.

3.

4.

5.

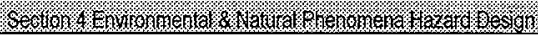

Environmental Qualification Required:

If yes: Environmental Qualification Requirements

Yes [ ]

Limiting Environmental Conditions:

No [X]

Required Safety Functions:

Environmental Condition B Qualification Period:

Natural Phenomena Hazard (NPH) Design Required:

Yes [ $\mathbf{X}]$

If yes: NPH Design Requirements

No [ ]

Performance Category: PC-3

NPH Design Req'ts.: Seismic Condition A

HNF-PRO-97, Rev. 0

W-441-P4, Rev. 2

Required Safety Functions: Pressure Boundary Integrity; Non-Powered Local Indication Monitoring of MCO Pressure for $\mathrm{H} 2$ Explosion

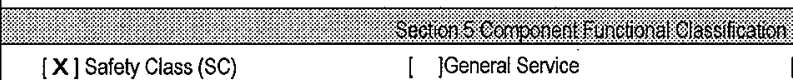

If part/component classification is different from host component/system, document basis.

\begin{tabular}{|c|c|c|}
\hline ל, & 5 & \\
\hline $\begin{array}{l}\text { National Codes/Standards: IEEE } 344 \text {, } \\
\text { IEEE 379, IEEE 603, IEEE } 627\end{array}$ & $\begin{array}{l}\text { Safety Analysis Report (SAR): } \\
\text { HNF-SD-SNF-SAR-002, Rev. } \\
\text { 4A }\end{array}$ & $\begin{array}{l}\text { Drawings: H-1-82161, Rev. } 2 \\
\text { HNF-SD-SNF-SEL-002, Rev. } 4\end{array}$ \\
\hline
\end{tabular}

Vendor Manuals/Manufacturer/Supplier information: Reotemp Instrument Corporation, Pressure Gauges, Series PR

Other: 
Commercial Grade Item Upgrade Dedication Form

Title: REOTEMP PRESSURE INDICATOR, LOCAL INDICATION OF MCO PRESSURE

\begin{tabular}{|c|c|c|c|c|}
\hline $\begin{array}{l}\quad \text { Critical Characteristics } \\
\text { Verification Document: Vendor } \\
\text { Specifications } \\
\text { HNF-SD-SNF-SEL-002, Rev. } 4\end{array}$ & Acceptance Criteria/Tolerances & $\begin{array}{l}\text { Acceptance } \\
\text { Method }\end{array}$ & ID & Function \\
\hline \multicolumn{5}{|c|}{ 1. Item Identification Critical Characteristics (necessary for reasonable assurance that the Item delivered is the ltem specified) } \\
\hline Nameplate Data & Per Vendor Manual & $1, \mathrm{IN}$ & $\mathbf{x}$ & \\
\hline Model Number & PR-25-S-1-A-4-P15-D & $1, \mathrm{IN}$ & $\mathbf{x}$ & \\
\hline Manufacturer & Reotemp & $1, \mathrm{IN}$ & $\mathbf{x}$ & \\
\hline \multicolumn{5}{|c|}{ 2. Physical Critical Characteristics (necessary for reasonable assurance that the ltem delivered is the Item specified) } \\
\hline Material, Body & Stainless Steel & $1, \mathrm{~T}$ & $\mathbf{x}$ & \\
\hline Process Connection & $\begin{array}{l}\text { Stainless Steel; } \\
1 / 4 " \text { NPT With } 1 / 4 " \times 1 / 2^{\prime \prime} \\
\text { Bushing; Bottom Mounted }\end{array}$ & $\begin{array}{l}1, T \\
1, I N\end{array}$ & $\begin{array}{l}\mathbf{x} \\
\mathbf{x}\end{array}$ & \\
\hline Indicator Range & $0-15$ psig & 1, IN & $x$ & \\
\hline Dial Diameter & Nominal 2.5 Inches & $1, \mathrm{IN}$ & $\mathbf{x}$ & \\
\hline \multicolumn{5}{|c|}{$\begin{array}{l}\text { 3. Performance Critical Characteristics (necessary \& sufficient for reasonable assurance that the Item will perform its intended } \\
\text { safety function(s)) }\end{array}$} \\
\hline Pressure Boundary Integrity & $\begin{array}{l}\text { No Leakage at Test Pressure of } \\
165 \text { Psig. Note } 2 \text {. }\end{array}$ & $1, T$ & & $\mathbf{x}$ \\
\hline Operating Range/Accuracy & $\begin{array}{l}0.15 \text { psig; }+1-1.6 \% \text { of full } \\
\text { scale. Expose gauge to } \\
\text { vacuum and retest per Note } 4 \text {. }\end{array}$ & $1, T$ & & $x$ \\
\hline Environmental & Note 1 & & & \\
\hline Seismic Condition A & Note 3 & $1, T$ & & $\mathbf{x}$ \\
\hline
\end{tabular}


Title: REOTEMP PRESSURE INDICATOR, LOCAL INDICATION OF

MCO PRESSURE

4. Notes and Legend:

1. The pressure indicator is not subject to degradation at ambient conditions of $40^{\circ} \mathrm{F}$ and $60 \% \mathrm{RH}$ or $115^{\circ} \mathrm{F}$ and $22 \% \mathrm{RH}$ and is suitable for Environmental Condition B application.

2. Pressure test at $\mathbf{1 1 0} \%$ of design accident condition pressure of 150 psig. Exposure to test pressure may seriously degrade the readout function. This test is considered to be a destructive test.

3. Maintain critical function after seismic event. W-441-P4, Rev. 2, Appendix L, page $L$ - 2 , provides a seismic testing plan for these components at a (TBD) seismic spectra.

4. This gauge will be exposed to vacuum during operations (nominal $13 \mathrm{kPa}$ to $20 \mathrm{kPa}$ ). The gauge must sustain the vacuum condition without affecting its readout accuracy within the 0-15 psig indication range of the gauge when the process pressure returns to above atmospheric.

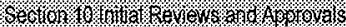

Approvals:

Designated Engineer: Em trang $12 / 2 / 98$

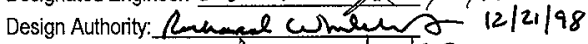

QA Engineer: TDD blayp 12122198

\section{Acceptance Method:}

1. Special Test and Inspection

$1, \mathrm{IN}$ for Inspection

1,T for Test

2. Commercial Grade Survey

3. Source Verification

4. Vendor/ltem History 


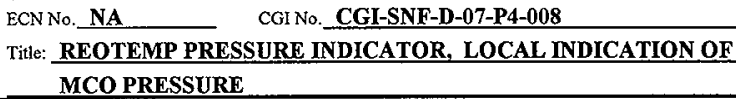

\begin{tabular}{|c|c|c|}
\hline \multicolumn{3}{|c|}{$\begin{array}{c}\text { WORKSHEET } 1 \\
\text { DETERMINATION OF FAILURE MECHANISMSIMODES }\end{array}$} \\
\hline \multicolumn{3}{|c|}{ SEC,10HX } \\
\hline \multicolumn{2}{|l|}{$\begin{array}{l}\text { Typical Failure } \\
\text { Mechanisms }\end{array}$} & $\begin{array}{l}\text { Applicable to Component } \\
\text { under Evaluation }\end{array}$ \\
\hline Fracture & $\begin{array}{l}\text { Separation of a solid accompanied by little or no } \\
\text { macroscopic plastic deformation. }\end{array}$ & $\begin{array}{l}\text { Yes [ ] No [X]; If Yes; indicate } \\
\text { failure Mode. }\end{array}$ \\
\hline Cortosion & $\begin{array}{l}\text { The gradual deterioration of a material due to } \\
\text { chemical or electrochemical reactions, such as }\end{array}$ & $\begin{array}{l}\text { Yes [ ] No [X]; If Yes, indicate } \\
\text { failure Mode_. }\end{array}$ \\
\hline Erosion & $\begin{array}{l}\text { Destruction of materials by the abrasive action of } \\
\text { moving fluids, usually accelerated by the presence } \\
\text { of solid particles carried with the fluid. }\end{array}$ & $\begin{array}{l}\text { Yes [ ] No [X]; If Yes, indicate } \\
\text { failure Mode }\end{array}$ \\
\hline Open Circuit & $\begin{array}{l}\text { An electrical circuit that is unintentionally broken so } \\
\text { that there is no complete path for current flow. }\end{array}$ & $\begin{array}{l}\text { Yes [ ] No [X]; if Yes, indicate } \\
\text { failure Mode_ }\end{array}$ \\
\hline Short Circuit & $\begin{array}{l}\text { An abnormal connection by which an electrical } \\
\text { current is connected to ground, or to some } \\
\text { conducting body, resulting in excessive current flow. }\end{array}$ & $\begin{array}{l}\text { Yes [ ] No [X]; If Yes, indicate } \\
\text { failure Mode_ }\end{array}$ \\
\hline Blockage & $\begin{array}{l}\text { Clogging of a filtering medium resulting in the } \\
\text { inability to perform its purification function or } \\
\text { blockage of flow. }\end{array}$ & $\begin{array}{l}\text { Yes [ ] No [X]; If Yes, indicate } \\
\text { failure Mode }\end{array}$ \\
\hline Seizure & $\begin{array}{l}\text { Binding of a normally moving item through excessive } \\
\text { pressure, temperature, friction, jamming. }\end{array}$ & $\begin{array}{l}\text { Yes [ ] No [X]; If Yes, indicate } \\
\text { failure Mode }\end{array}$ \\
\hline Unacceptable Vibration & $\begin{array}{l}\text { Mechanical oscillations produced are beyond the } \\
\text { defined permissible limits due to unbalancing, poor } \\
\text { support, or rotation at critical speeds. }\end{array}$ & $\begin{array}{l}\text { Yes [ ] No [X]; If Yes, indicate } \\
\text { failure Mode__ }\end{array}$ \\
\hline Loss of Properties & $\begin{array}{l}\text { A loss of mechanical and physical properties of a } \\
\text { material due to exposure to high temperatures, } \\
\text { radiation exposure. }\end{array}$ & $\begin{array}{l}\text { Yes [ ] No [X ]; If Yes, indicate } \\
\text { failure Mode }\end{array}$ \\
\hline Excess Strain & $\begin{array}{l}\text { Under the action of excessive external forces the } \\
\text { material of the part has been deformed or distorted. }\end{array}$ & $\begin{array}{l}\text { Yes [ ] No [X]; If Yes, indicate } \\
\text { failure Mode }\end{array}$ \\
\hline Mechanical Creep & $\begin{array}{l}\text { From prolonged exposure to high temperature and } \\
\text { stress, the object will show a slow change in its } \\
\text { physical (shape and dimension) and mechanical }\end{array}$ & $\begin{array}{l}\text { Yes [ ] No [X]; If Yes, indicate } \\
\text { failure Mode }\end{array}$ \\
\hline Ductile Fracture & $\begin{array}{l}\text { Fracture characterized by tearing of metal } \\
\text { accompanied by appreciable gross plastic } \\
\text { deformation. }\end{array}$ & $\begin{array}{l}\text { Yes [ ] No [X]; If Yes, indicate } \\
\text { failure Mode. }\end{array}$ \\
\hline \multicolumn{3}{|c|}{ 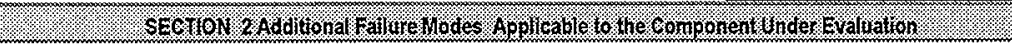 } \\
\hline \multicolumn{3}{|c|}{ 1. Gauge Movement Mechanism Failure } \\
\hline \multicolumn{3}{|c|}{ 2. Process Connection/Body Break } \\
\hline
\end{tabular}


CHECKLIST 1

ACCEPTANCE METHOD 1

SPECIAL TESTINSPECTION VERIFICATION

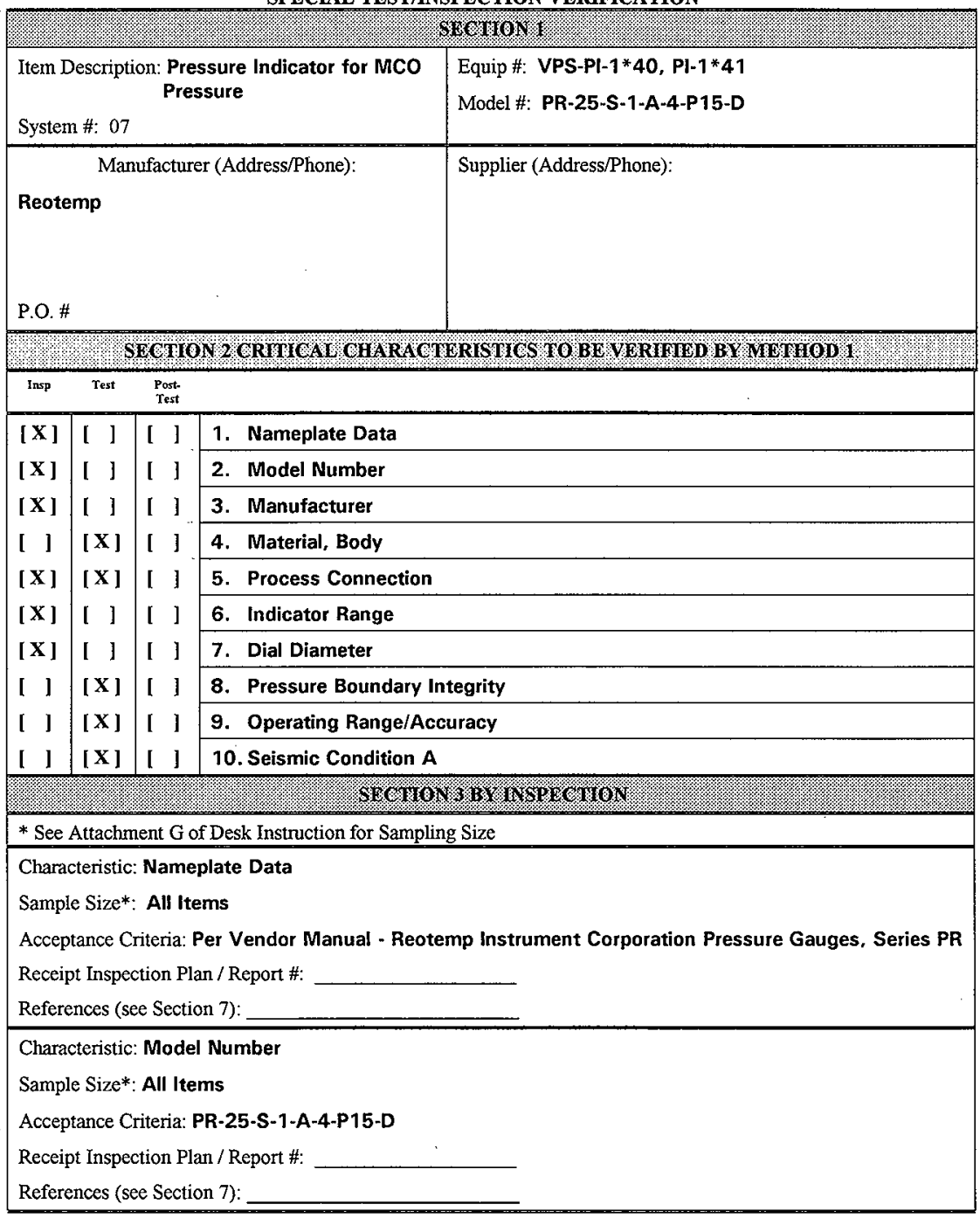



MCO PRESSURE

\author{
Characteristic: Manufacturer \\ Sample Size*: All Items \\ Acceptance Criteria: Reotemp \\ Receipt Inspection Plan / Report \#: \\ References (see Section 7): \\ Characteristic: Indicator Range \\ Sample Size*: All Items \\ Acceptance Criteria: 0-15 Psig \\ Receipt Inspection Plan / Report \#: \\ References (see Section 7): \\ Characteristic: Dial Diameter \\ Sample Size*: All Items \\ Acceptance Criteria: Nominal 2.5 Inches \\ Receipt Inspection Plan / Report \#: \\ References (see Section 7): \\ Characteristic: Process Connection \\ Sample Size*: All Items \\ Acceptance Criteria: 1/4" NPT With 1/4" X 1/2" Bushing; Bottom Mounted \\ Receipt Inspection Plan / Report \#: \\ References (see Section 7):
}




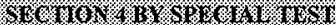

* See Attachment G of Desk Instruction for Sampling Size

Test To Be Performed by:

Number of Items to be Tested:

[ ] Purchaser

[ ] Supplier/Manufacturer**

Test/Inspection Location:

[ ] Other

Characteristic for Test: Material, Body

Acceptance Criteria: Stainless Steel

Sample Size*: Normal Sampling Size

Actual Test Value:

Test Plan and Report \#:

References (see Section 7):

Characteristic for Test: Material, Process Connection

Acceptance Criteria: Stainless Steel

Sample Size*: Normal Sampling Size

Actual Test Value:

Test Plan and Report \#:

References (see Section 7):

Characteristic for Test: Pressure Boundary Integrity

Acceptance Criteria: No Leakage at Test Pressure of 165 Psig

Sample Size*: Destructively Test Only One Item

Actual Test Value:

Test Plan and Report \#: References (see Section 7):

Characteristic for Test: Operating Range/Accuracy

Acceptance Criteria: 0-15 psig; $+/-1.6 \%$ of full scale. Expose gauge to vacuum and retest.

Sample Size*: Normal Sampling Size

Actual Test Value:

Test Plan and Report \#: References (see Section 7):

Characteristic for Test: Seismic Condition A

Acceptance Criteria: : Maintain Critical Function After Seismic Event. W-441-P4, Rev. 2, Appendix L, page L-8, provides a seismic testing plan for these components at a (TBD) seismic spectra.

Sample Size*: Normal Sampling Size

Actual Test Value:

Test Plan and Report \#: References (see Section 7):

**If Supplier/Manufacturer or Other, Refer to CGI Checklist-2 for Support Information 


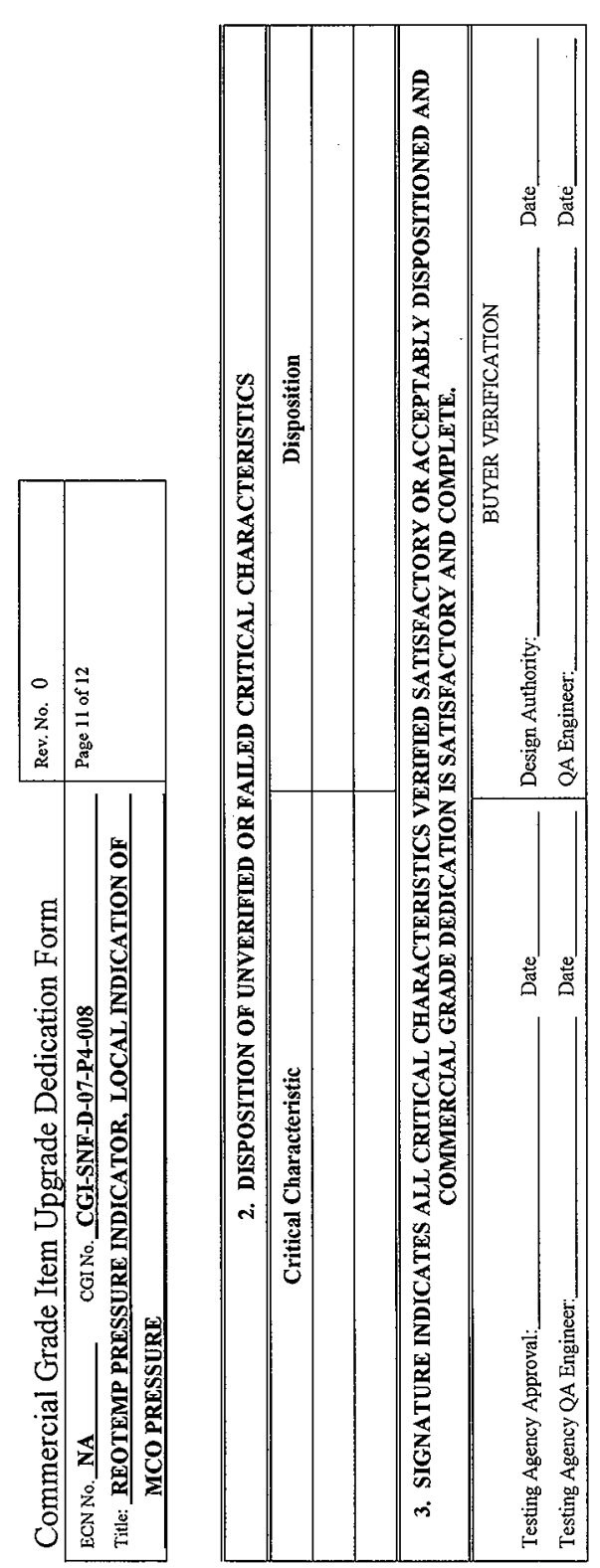

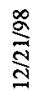


Commercial Grade Item Upgrade Dedication Form

ECNNo.NA CGI No._GI-SNF-D-07-P4-008

Title: REOTEMP PRESSURE INDICATOR, LOCAL INDICATION OF MCO PRESSURE

\begin{tabular}{|c|c|}
\hline Name & Phone \\
\hline Design Authority & ( ) \\
\hline QA & ( ) \\
\hline $\mathrm{QC}$ & ( ) \\
\hline Cog - Engineer & ( ) $)$ \\
\hline CGI Engineer & ( ) \\
\hline Procurement Engineer & ( \\
\hline Other & $(\quad)$ \\
\hline \multicolumn{2}{|c|}{ 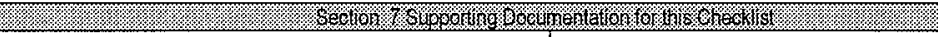 } \\
\hline Initial Procurement Documents & For Critical Characteristics \\
\hline [ ] Drawings: & \\
\hline [ ] Manuals (specify type \& number): & \\
\hline [ ] Design Calculations & \\
\hline [ ] Installation Instructions & \\
\hline [ ] Operation Instructions & \\
\hline [ ] Calibration Instructions & \\
\hline [ ] Manufacturer's Recommended Spare Parts List & \\
\hline [ ] Other: & \\
\hline Procurement Documents & \\
\hline [ ] Certificate of Conformance/Compliance & \\
\hline [ ] Seismic Qualification Certificate & \\
\hline [ ] Environmental Qualification Certificate & \\
\hline [ ] Test Report (s): & \\
\hline [ ] Inspection Report (s): & \\
\hline [ ] CMTRs for ASME Pressure Retaining Materials & \\
\hline [ ] Valve Seat Leakage Report & \\
\hline [ ] Weld Records & \\
\hline [ ] Material Traceability Record & \\
\hline [ ] Other: & \\
\hline
\end{tabular}

